\title{
Spiritual Journey of Murut Tahol in Sabah and Its Effect to Their Headhunting Practice
}

\author{
Abd Hakim Mohad
}

\begin{abstract}
Religion has a strong influence on the world view of a society. It also affects the actions and practices of everyday life. Therefore, changes in the religion also result in changes in religious practice. This paper tries to see the impact of religious change on headhunting (antaboh) in Tahol Murut community, Ulu Tomani, Sabah, Malaysia. This is because, originally, these people are holding on to faith-based ancestral spirits. Headhunting (antaboh) that they practiced for a long time, is based on traditional religion and belief which has existed for many generations. However, having come into contact with the Lun Bawang people who are Christians, they eventually were drawn to accept Christianity as their religion beganning around the 1950s. Thus, the effect of changes in religion in this community is interesting to be discussed. At least we can assess whether the view that religious change gives impact on the culture of a community also applies to this community. The Methodology used in this study is qualitative in nature involving library research and interview key informants. The researcher also had the opportunity to be with this community on a regular basis from 2003 until today. The result of this study revealed that religious change of Murut Tahol community give significant effect to their headhunting practice.
\end{abstract}

Index Terms-Murut tahol, religious change, headhunting.

\section{INTRODUCTION}

Religious life is basically a belief in the existence of supernatural powers, extraordinary or supernatural influence on the lives of individuals and society, and all natural phenomena. Credence to cause certain behaviors such as praying, worshiping, and others, as well as give rise to certain mental attitudes like fear, optimism, resignation of the individuals and communities who believe [1]. It means religion colored and shaped culture. Religion influenced with the way people think and act, then the religion is often relied upon to social conduct or practice. Therefore, the changes on religion will affect the social practice which based on the previous religion. Their perceptions of past lives and practices may change [2].

Murut Tahol community is one of the examples, as they put religion as a reason in cultural practices such as headhunting (antaboh). However, the religion and traditional beliefs which secures the practice has been steadily eroded and abandoned. At the present time this community had converted to Christianity. It is good to ask, whether the

Manuscript received July 24, 2013; revised September 26, 2013. This work was supported by Universiti Malaysia Sabah as part of Ph.D. research titled Social Change of Murut Tahol at Ulu Tomani, Sabah, Malaysia. This research is in the field of Sociology and Social Anthropology.

Abd Hakim Mohd Mokhtar is with the Universiti Malaysia Sabah, Jln. UMS, 88400 Kota Kinabalu, Sabah, Malaysia (e-mail: abdhakimmy@yahoo.co.uk, abdhakim@ums.edu.my). religious changes of Tahol Murut community, give affects to the practice of headhunting (antaboh) that they practiced before. This will be discussed in depth.

\section{Murut TAHOL}

Murut Tahol community originated from the settlements on the Tahol river located in Pensiangan before moving to other areas. They often identify themselves as Ulun Tahol which means the Tahol man. Based on the early writings made around the end of 1800 showed that the Murut Tahol community has been inhabited at Padas river valley that time [3], [4].

They practice shifting cultivation by planting upland rice as the main crop. At the same time they are also cultivate other crops such as corn and tapioca. In addition, they are also hunt in the jungle nearby and fishing. In terms of language, they speak their own language which is considered as one of the Murutic language. It is widely spoken language in the South West Sabah, including the administration of Keningau, Tenom, Sipitang, Pensiangan, Merotai, Tawau and beyond Indonesian border in Borneo. In addition, it is also spoken in the Beaufort, Tawau and Kinabatangan. Based on studies conducted by Spitzack (1984) in Sabah, actually Murutic languag consist of twelve languages, those are Gana, Keningau (dialect Apin-Apin Kuijau, Dusun-Murut, Ambual, Nabai), Timugon, Beaufort, Bookan ( Bookan and Tangara dialect), Paluan (Paluan and Pandawan dialect), Sumambu / Tagal (Pensiangan, Salalir, Rundum, Tomani and Maligan), Kolod, Selungai, Sembakung, Kalabakan and Serudung [5]. Murut Sumambu / Tagal Murutic classified as the largest language family in 1980 with the number of speakers 13,000-14,000 people [6].

Based on Harris's notes, Murut Tahol community live in highlands covered with thick forest. This resulted in their area being relatively isolated and inaccessible. In a sense, this isolation has to do with the practice of head hunting (antaboh) that has been passed over the years. This community often attack nearby villages for this purpose [7].

\section{TRAditional BeliEF}

Murut Tahol community believe that Aki Kaulung is the main source of power, also known as the beginning of the universe. Aki Kaulung in Murut Tahol means grandfather, source of existance; while Kaulung means the largest or greatest. According to their belief all these creation such as land, sea, hills, mountains, rivers, plants, animals and human beings are the creation of Aki Kaulung. All these things have their own spirit and influence people's lives. 
This community believes that people should play a wise role in administering and managing the world. Man must strive to find their own life using the resources provided by Aki Kaulung. When they die, the human spirit rises to the sky (limbowon) to meet Aki Kaulung, then undergo eternal life.

\section{HEADHUNTING (ANTABOH)}

Headhunting (antaboh) is important to Murut Tahol community as it is believed to help their souls to meet Aki Kaulung when they die. Headhunting (antaboh) practice meant to take the spirit of his opponent, then the spirit is in his opponent would penetrate his body. This will increased his spiritual strength. Spiritual strength is very important for them to infiltrate of large caterpillars (batol) before they can meet with Aki Kaulung. For women and children who are not involved with headhunting (antaboh) practice, they can get help from their family members who joined headhunting (antaboh). They believe that the strength of the spirit of a family member can help other family members.

According Antikoh Lituan, before a person's spirit can meet Aki Kaulung, he was forced through the narrow and straight path in front of him there is a snag in the form of a big caterpillars (batol). They believe, the stronger the spirit of a person, then the easier it can pass the caterpillars' (batol) hitch. After that then their spirits can meet Aki Kaulung at upper world (limbowon). This belief is actually a source of motivation to perpetuate the practice of headhunting (antaboh) in their circles.

In addition, headhunting (antaboh) became a symbol of heroism of Murut men. They are very proud of this tradition and each head brought to long house is greeted with joy. This practice binds and unites them and thereby making community organized and comply with customs and traditions of their ancestors. This custom is also the core of the lives of those associated with the spirit and the supernatural aspect [8].

However, this practice has been banned by the BNBCC (British North Borneo Charted Company) administration. This was one of the reasons Murut community fought BNBCC in 1915, lead by Ontoros at Rundum [9], [10]. After the incident, this community choose to adapt to the situation, where they need to get along to the BNBCC administration. They obey the law imposed to them, although it is an important practice in their traditional culture. Antikoh Lituan said, "after the death of Ontoros, we follow the company rules. Even though headhunting (antaboh) is important but we do involve anymore. We live in the jungle, planting up land paddy, cassava, maize. However, there are also counted among those who ignored the ban". Although their numbers is small, but It can prove that they were actually still hold on to this traditional customs. This situation continues up to the reign of Japan. They have made Japanese army as the main target. Indeed, a lot of stories about how they have been beheaded by the Murut people.

To discontinue the practice of headhunting (antaboh) certainly disturbing aspect of their spiritual and social balance and emotional affect society. Conley (1974) have posted about this in his study involving Kenyah; he stated:

"In the same way with the headhunting institution of the
Kenyah, its rapid cessation would produce serious social and emotional disequilibrium" [11].

\section{EMBRACE CHRISTIAN}

In fact, efforts to introduce Christianity to the Murut Tahol community was conducted in 1930 by missionaries from Indonesia. However, this attempt fails and then they come out of the box due to the Murut Tahol as the responses received is unexpected and quite dangerous. In 1937, missionaries from the Borneo Evangelical Mission (BEM) has been coming to them for the same purpose. Their efforts also failed.

After that no more missionaries were sent to the Murut Tahol. Instead they focus more to the Lun Bawang people who really interested in Christianity. However, an unexpected move from Murut Tahol society has happened when in 1950, a total of 50 people from Maligan Murut Tahol have come to Sipitang and met with Alan Belcher and asked him to teach them about the Bible. They demanded Alan Belcher to send a missionary to them immediately. Their openness to accept Christianity began when they see the positive changes that occur to the Christian community who live nearby, that is Lun Bawang. However, because of all the missionaries already had jobs and commitment, then Alan Belcher suggested to them to send a couple to the School of the Bible .

As a result of these discussions, the community agree to send two couples Lutus and Impau to study Christianity in Bible School in Lawas. During the semester, they have to gather people in Maligan and share their knowledge. Then, in 1951, Alan Belcher had the opportunity to visit Maligan. During the few days of being there, he, along with Impau and Lutus had had a meeting with the villagers [12]. Next, in 1952, a church was built in Maligan [13].

After professing Christian, Murut Tahol community in Maligan has experienced some positive changes. They are no longer associated with various diseases caused by unhygienic environment. Instead, they have been known as a healthy and more advanced in everyday life. This is because the church also runs educational programs in their place. The story of the two mothers and their children who suffer anemia successfully cured by eating vegetables, while it is a taboo according to traditional beliefs, have spread to the surrounding area. They get very excited to recognize the Christian who has freed them from the shackles of traditional beliefs. This results lead Murut Tahol people from Ulu Tomani to come and ask about Christianity. They had built a house for the pastor and 50 families were willing to convert to Christianity en masse. By reason Impau was asked by his brother to continue to live and serve in Maligan, then a new missionary named Amat been appointed in Ulu Tomani [14].

Christianity began to take on faith of Murut Tahol community when their traditional belief has eroded. Gradually they began to consider other beliefs that might be able to fill the vacuum left. News about success achieved by the Lun Bawang and Murut Tahol in Meligan after professing Christian, has prompted them to approach religion. Initiative to learn the teachings of Christian and missionaries persistence has motivate them to be committed Christian. 
Apart from the factor of confidence in the truth of Christian teachings attributed to extraordinary events or miracles experienced by them and the villagers, there are also other factors that attract them to embrace Christianity.

One of the important factors, they say that Christianity is a religion of love and peace and reject human rivalry. God's love was manifested in the form of forgiveness of sins and an offense to human error. This causes their lives in peace and harmony without fear of becoming targets of violence by any body or punished as a result of offenses committed. Unlike the traditional beliefs that have an element of intimidation and threats, where they are required to adhere to all customs and taboos in order to obtain salvation, or survived from evil spirits. If not, they will be punished without mercy immediately in various forms such as droughts, floods and death. Between the two forms of this belief, they are more attracted to choose a belief based on God's love. This is expressed by the informants to say "...living in love is better than living in fear. Moreover, when we have done something wrong, we can only pray, ask for forgiveness. No need to do that, this ..., as before."

\section{EFFECT OF Religious Change}

In reality, Christians have succeeded in dismantling Murut Tahol traditional religion in Kampung Alutok. Thus, we can see the effect on the community cultural practices. Cultural practices that were once important to them, but now has been abandoned because according to them it is incompatible with the basic principles of the Christian religion they profess. No doubt that headhunting (antaboh) practice was discontinued because of BNBCC law, but after receiving the Christian faith, they quit it voluntarily on the basis of religion to respect the rights of others. While at one time, was a very significant custom and become Murut Tahol identity. According to pastor Yusof, "... in the period of BNBCC administration, the Murut Tahol stop headhunting because of forced. But now, voluntarily, for Christianity invites all men love each other."

The indigenous belief have been deprived of this subtly when they accepted Christianity as a religion that replaced their traditional religion which based on animism. Their view of the head hunting practice antaboh has also changed. If the first It symbolizes the nature of heroism and believed could help them prepare to meet with Aki Kaulung, but now It is regarded as behavior contrary to the principles of humanity. According to informant,"... all of us leave traditional headhunting (antaboh) because it is bad and cause animosity among people". This expression represents the actual value changes in society that have a direct connection with the Christian teachings.

According to Antikoh Lituan, become a christian, indirectly relieve them of headhunting (antaboh), a customary practice that could endanger themselves, their families and society as a whole. He added, "... after become christian, we live more calmly. No need to go for headhunting (antaboh), we are also not to worry about the fate of the people who go for headhunting (antaboh)". This view thus shows us about the success of Christianity changed the world view of Tahol Murut community.

In other words, their perception of life has changed. In line with changes that happen to their religion. In the context of traditional societies, religious change or conversion saw a big influence. Because every religion has its own beliefs about the supernatural, extraordinary or supernatural, so it produces a different personality and culture to its adherents. Thus, the religious changes that occur in a society can be seen as one of the factors in a change to the community. This is because religion has an influence on other aspects of life through the interactions with other social institutions. The effect can be seen in material aspects human behavior, values, morals, family systems, economics, law, politics, medicine, science, technology, art, rebellion, war and so on. Religion is the most important aspect of culture which give wider influence and implications in human life [15].

Therefore, the change of religion is not something that can be considered small or light either for the individuals involved or the surrounding society. This is because the change of religion is not only a change in the belief system of the individual but also have an impact on everyday life and how they perceive life. The nature of the change was highly dependent on the level of their understanding of religious affiliation. Deepening their appreciation to the religion, the more far old religious practices that they leave [16].

\section{CONCLUSION}

This studies is important to understand the key factors that lead to social change and its effects in this society in particular. Of course, for some people changes is every where. So, why bother? Actually the result of this research give an idea about the next change that may occurred in this society, which regards to their culture and way of life. It is because, religious change is not only involve ritual practice. Change of world view and perception of life will affects their culture in depth.

\section{ACKNOWLEDGMENT}

Author thanks Murut Tahol people in Ulu Tomani for their commitments and supports in this research. A special thanks is dedicated to Antikoh Lituan for sharing his knowledge and experience. Last but not least, I would like to address my appreciation to Universiti Malaysia Sabah for the scholarship and study leave to conduct this research.

\section{REFERENCES}

[1] B. Agus, Agama dalam Kehidupan Manusia, Jakarta: PT RajaGagindo, 2005, pp. 1.

[2] W. S. Simons, Islamic Conversion and Social Change in a Seneglese Village, Ethnology, vol. XVIII, no. 4. October. 1971, pp. 303.

[3] A. S. Harris, "The Tagal Murut," in Social Organisation of Sabah Societies, Sherwood, Kota Kinabalu: Sabah Museum, 1990, pp. 39.

[4] T. Harrisson, "Ethnological Notes on The Muruts Sapulut River, Sabah," Journal of Malayan Branch, Royal Asiatic Society, vol. 40, no. 1, pp. 111,1967

[5] J. A. Spitzack, “The Murutic Language Family," Languages of Sabah: A Survey Report, Australia: The Australian National University, pp. 189, 1984.

[6] J. A. Spitzack, "The Murutic Language Family," Languages of Sabah: A Survey Report, Australia: The Australian National University, pp. 157,1984

[7] A. S. Harris, "The Tagal Murut," in Social Organisation of Sabah Societies, Sherwood, Kota Kinabalu: Sabah Museum, pp. 41, 1990.

[8] A. Lituan, 65 Years Old, Ulu Tomani, Sabah. 
[9] F. G. Whelan, A History of Sabah, Kuala Lumpur: MacMillan and Co (s) Private Ltd, 1970, pp. 185.

[10] Fernandez, "Perkembangan ekonomi penjajah dan penentangan masyarakat murut: Pemberontakan rundum 1915," in Sabah dalam Perluasan Pasaran, Abdul Halim Ali, Bangi: Penerbit Universiti Kebangsaan Malaysia, pp. 80, 2000.

[11] W. W. Conley, "Kenyah Receptivity and Response to Christianity," in Sarawak Museum Journal, Jerome Rousseau, vol. 22, no. 43, pp. 314, 1974.

[12] S. P. Lees, Drunk Before Dawn, Kuala Lumpur: Sama Publications and Distribution Sdn Bhd, 2006, pp.104.

[13] A. S. Harris, "The impact of christianity on power relationships and social exchanges: A case study of change among Tagal Murut, Sabah, Malaysia," Ph.D dissertation, School of Inter Culture Studies, Biola University Michigan: UMI Dissertation Service, pp.10-11, 1995.

[14] S. P. Lees, Drunk Before Dawn, Kuala Lumpur: Sama Publications and Distribution Sdn Bhd, pp.106-107, 2006.

[15] B. Agus, Agama dalam Kehidupan Manusia, Jakarta: PT RajaGagindo, 2005, pp. 3-5.
[16] H. M. Nor, Salib dalam Komuniti Pinggiran, Kota Kinabalu: Universiti Malaysia Sabah, 2001, pp. 27.

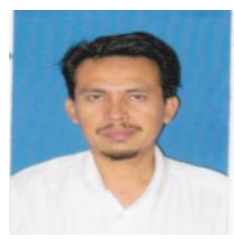

Abd Hakim Mohad was born in Muar, Johor Malaysia in 1972-07-10. He obtained his first degree from International Islamic University (IIUM), Selangor in the field of Human Science in 1997 Later, he earned his Master degree in Civilization Studies from University of Malaya (UM), Kuala Lumpur Malaysia in a year 2000. He graduated his Ph.D. program in Sociology and Social Anthropology at Universiti Malaysia Sabah in 2011. He works at Universiti Malaysia Sabah since 2003 until now. His current position is senior lecturer. Among his latest publications are Social Exchange in Ritual Abis Pantang Murut Tahol Sapulut, Sabah (2011), Adat dan Ritual Kematian Suku Murut Tahol di Sabah (2010), Malaysian Contributions to Dialogue among Civilization (2009). He also served as editor for MANU Journal from 2004-2006, Center for the Promotion of Knowledge and Language, Universiti Malaysia Sabah. 